\title{
Editorial
}

Dermatology

\section{The First Description of the Hair Follicle Bulge by Franz von Leydig}

\author{
Marlon R. Schneider \\ Institute of Molecular Animal Breeding and Biotechnology, Gene Center, Ludwig-Maximilian University Munich, \\ Munich, Germany
}

More than 20 years ago, Cotsarelis et al. [1] published an article in which they showed that a region of the mouse hair follicle known as the 'bulge' contains a population of slow-cycling label-retaining cells. Additional studies revealed that these cells are multipotent stem cells, whose activation during early anagen allows the initiation of a new hair cycle (the so-called 'bulge activation hypothesis' [2]). Since then, the biological properties of the bulge stem cells have been intensively studied [3,4]. Although additional sites bearing stem cells have been identified along the hair follicle $[5,6]$, the importance of the bulge as the essential reservoir of hair follicle stem cells remains undisputable.

Before the 1990s, the bulge attracted little attention from researchers, mainly because it was rarely identified in routine paraffin sections of adult human hair follicles. With the sudden interest in the bulge, a variety of statements regarding its first description were made. Authors often credit Paul Gerson Unna [7] and Philipp Stöhr [8] for the 'discovery' of the bulge, a (erroneous) belief that can be traced back to The Biology of Hair Growth, a classic dermatology textbook [9]. The more recent history of bulge research has been reviewed by Arve Madsen [10], who acknowledges that the structure was initially named 'Wulst' by different German authors. The most detailed account of the initial descriptions of the bulge is given by Stöhr [8]. Stöhr provides a long list of publications mentioning the bulge and briefly discusses an alleged first description by the famous Austrian dermatologist Ferdinand von Hebra [11]. However, in the publication in question, Hebra merely reports a thickening of the hair follicle root sheath in lichenoid lesions; he does not employ the term 'Wulst' and since there is no accompanying picture, it is rather questionable whether the alterations he described correspond to the bulge of a normal hair follicle. According to Stöhr, the first description of the bulge of a normal hair follicle was made by Unna [7].

Here, I present evidence that the first description and detailed depiction of the hair follicle bulge was made almost two decades earlier by Franz von Leydig (18211908), a German histologist and zoologist most commonly known for the discovery of the testicular interstitial cells bearing his name, in an article entitled 'About the outer coats of mammals' [12]. Leydig (fig. 1) obtained a medical doctorate degree from the University of Würzburg in 1847 . He also spent his early career in Würzburg before becoming a professor of zoology in Tübingen in 1857. In 1875, Leydig moved to the University of Bonn, where he stayed until his retirement in 1887 . He died in 1908 in the town of his birth, Rothenburg ob der Tauber.

\section{KARGER \\ Fax +4161306 1234 \\ E-Mail karger@karger.ch \\ www.karger.com}

(C) 2011 S. Karger AG, Basel

$1018-8665 / 11 / 2231-0029 \$ 38.00 / 0$

Accessible online at:

www.karger.com/drm
Dr. Marlon R. Schneider

Gene Center, Ludwig-Maximilian University Munich

Feodor-Lynen-Strasse 25

DE-81377 Munich (Germany)

Tel. +49 89218076 815, E-Mail schnder@lmb.uni-muenchen.de 
1

Fig. 1. Portrait of Franz von Leydig. The picture was taken during his initial years in Tübingen and therefore around the time the article dealing with the hair follicle bulge was published. Reproduced with permission from the German Academy of Sciences Leopoldina, Halle/Saale, Germany.

Fig. 2. Leydig's drawing of a mouse whisker accompanying the article in which the bulge was first described (originally fig. 3). The bulge is indicated by ' $\mathrm{d}$ ', and the following is a translation of the legend Leydig provided for this figure: 'Bulged swelling of the hair root sheath'. The cavernous blood-filled sinuses (b, c) and the prominent nerve (e) are typical of the rodent vibrissae. The hair follicle capsule (a) and the sebaceous glands (f) are also indicated. Reproduced from a copy belonging to the $\mathrm{Ba}$ varian State Library in Munich (Bayerische Staatsbibliothek).

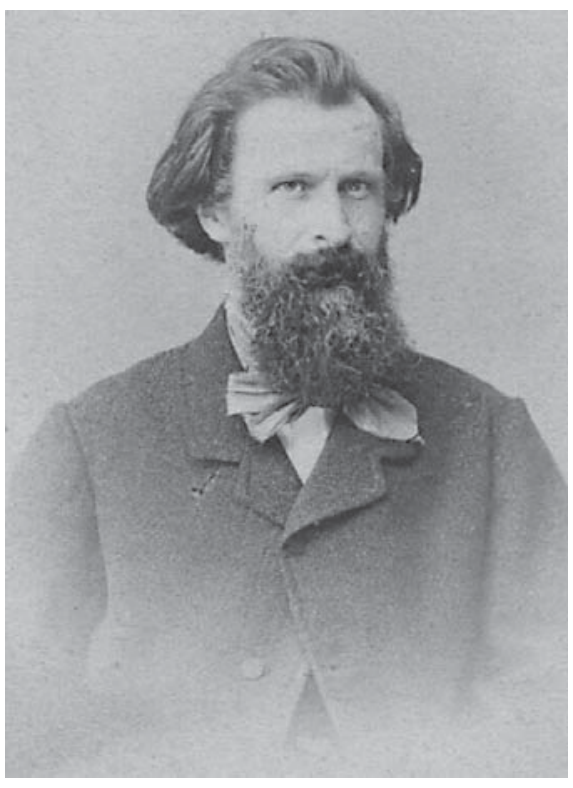

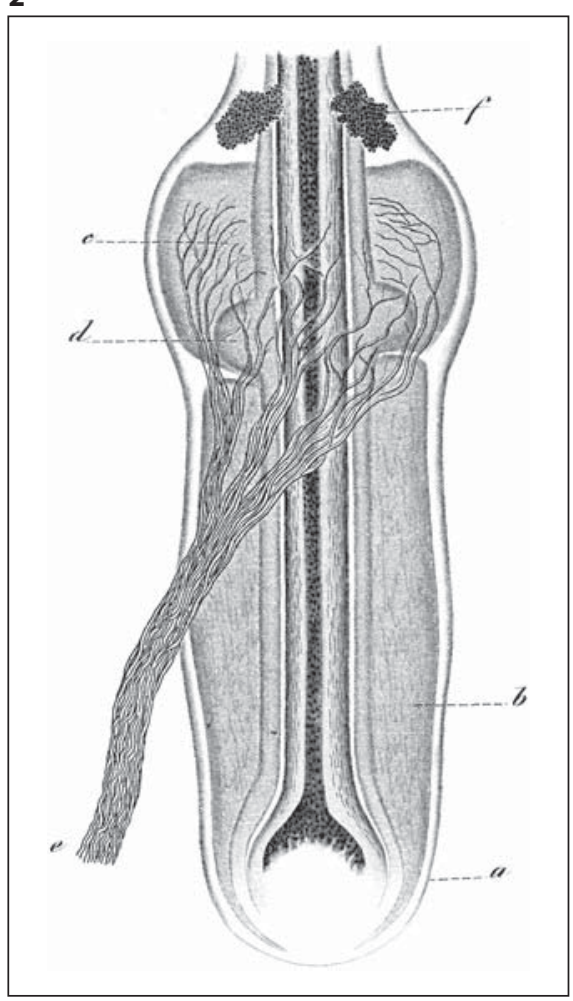

Leydig is often regarded as the founder of comparative histology, his interests including a wide range of aspects of both invertebrate and vertebrate microscopical anatomy [13].

The report relevant here [12] was published two years after Leydig took over the professorship in Tübingen. The article consists of 69 pages and two plates with a total of 13 figures, and is divided into 26 subchapters, some of them carrying peculiar titles such as 'The epidermis of the whale', 'Pulsating skin veins of bats' and 'Microscopical analysis of the skin from prehistoric mammals'. The description and depiction (fig. 2) of the bulge is given in a short chapter entitled 'Peculiar bulge of the root sheath' ('Eigenthümlicher Wulst der Wurzelscheiden'). The following is my translation of the chapter in question:

The root sheaths of the hair of many mammals feature another special structure, which to my knowledge has not received attention so far. It is a thickening or a circular bulge (ein ringförmiger Wulst), which is located on the upper third of the hair root. I first noticed the structure in question on the whiskers of the house mouse (compare fig. $3 \mathrm{~d}$ ), where one can see how the straight ascending root sheath suddenly projects out to both sides, albeit with only the outer root sheath contributing to this feature. A similar structure can be found on the whiskers of the dog. However, the bulge is also present in the ordinary coat hairs. I saw it for instance in the guinea pig, weasel, and platypus. The root sheath cells at this position are not uncommonly filled with a dark grainy content, causing the bulge, when observed in a longitudinal section, to resemble a pair of sebaceous glands budding out of the root sheath; I note, however, that the hair in question always possesses its developed sebaceous glands at the conventional position just ahead.

Leydig certainly benefited from the fact that the bulge is much easier to recognize in adult rodent hair follicles than in adult human hair follicles. Nonetheless, considering the imperfectness of the microscopes of Leydig's time and the lack of the most basic histological resources such as proper fixation methods, paraffin embedding, microtome sections and application of stains, the accurateness of Leydig's description of the bulge - consider for instance the observation that the bulge is limited to the outer root sheath - is notable.

Interestingly, Leydig's first biographer, the zoologist Otto Taschenberg, mentions that many of Leydig's findings suffered a similar fate and remained unknown to the scientific community, in many cases being eventually published by other authors as new discoveries some years later [14]. However, Taschenberg's explanation for this circumstance, the fact that Leydig often compiled quite 
unconnected observations into a single publication which frequently carried a title fully unrelated to the subject, definitely does not apply here. It remains therefore a mystery why Leydig's precise description of the bulge has been consistently overlooked.

\section{Disclosure Statement}

The author declares that there are no conflicts of interest or financial issues associated with this paper.

\section{References}

$>1$ Cotsarelis G, Sun TT, Lavker RM: Label-retaining cells reside in the bulge area of pilosebaceous unit: implications for follicular stem cells, hair cycle, and skin carcinogenesis. Cell 1990;61:1329-1337.

-2 Sun TT, Cotsarelis G, Lavker RM: Hair follicular stem cells: the bulge-activation hypothesis. J Invest Dermatol 1991;96:77S-78S.

13 Cotsarelis G: Epithelial stem cells: a folliculocentric view. J Invest Dermatol 2006;126: 1459-1468.

$\checkmark 4$ Ohyama M: Hair follicle bulge: a fascinating reservoir of epithelial stem cells. J Dermatol Sci 2007;46:81-89.

5 Schneider MR, Schmidt-Ullrich R, Paus R: The hair follicle as a dynamic miniorgan. Curr Biol 2009;19:R132-R142.
6 Jaks V, Kasper M, Toftgard R: The hair follicle-a stem cell zoo. Exp Cell Res 2010;316: 1422-1428.

7 Unna PG: Beiträge zur Histologie und Entwickelungsgeschichte der menschlichen Oberhaut und ihrer Anhangsgebilde. Archiv für mikroskopische Anatomie 1876;12:665741.

8 Stöhr P: Entwicklungsgeschichte des menschlichen Wollhaares. Anatomische Hefte Beiträge und Referate zur Anatomie und Entwicklungsgeschichte 1904;23:1-66.

9 Pinkus H: Embryology of hair; in Montagna W, Ellis RA, (eds): The Biology of Hair Growth. New York, Academic Press, 1958, pp 1-32.
10 Madsen A: Studies in the 'bulge' (Wulst) in superficial basal cell epitheliomas. Arch Dermatol 1964;89:698-708.

11 Hebra F: Acute Exantheme und Hautkrankheiten. Erlangen, Verlag von Ferdinand Enke, 1860.

12 Leydig F: Ueber die äusseren Bedeckungen der Säugethiere. Archiv für Anatomie, Physiologie und wissenschaftliche Medicin 1859:677-747.

13 Schneider MR: Franz von Leydig (18211908), pioneer of comparative histology. J Med Biogr 2011, in press.

14 Taschenberg O: Franz von Leydig. Ein Nachruf für den Nestor der deutschen Zoologen. Leopoldina 1909: 37-44, 47-52, 57-64, 70$76,82-88$. 